\title{
MESTRE BORIS E 0 SABER SOCIALIZADO
}

http://dx.doi.org/10.11606/issn.2237-1184.v0i26p101-111

\section{Maria Augusta Fonseca 1}

Universidade de São Paulo (USP)

Aquela manhã de janeiro de 1972 era de verão ardente. No espaço aberto dos barracões-colmeias no campus da Cidade Universitária reuniamse candidatos a vagas abertas pelo professor Boris Schnaiderman no Programa de Pós-graduação em Teoria literária e Literatura comparada. O grupo, que ali se juntava, estava aguardando a distribuição dos horários da entrevista. Em conversa de espera, soube que todos eram da USP e, quase todos, ex-alunos do curso de russo. Não fosse por minha determinação, teria desistido ali mesmo, porque não me encaixava naquele perfil específico e tinha pela frente um obstáculo: em 1966, aos 21 anos, tinha completado a graduação na assim chamada Faculdade de Filosofia, Ciências e Letras da Universidade Mackenzie. Muito embora, como alguns poucos, minha visão e a atuação à esquerda fossem diametralmente opostas ao espírito reacionário e belicoso que a representava e, pouco mais tarde, comprovado no ataque de truculência policialesca, desferido contra estudantes da USP, com a batalha na rua Maria Antônia, em 1968.

$\mathrm{Na}$ entrevista, feitas as devidas apresentações, a conversa se encaminhou para as literaturas de minha formação (português, inglês, espanhol). Particularmente, falei de meu entusiasmo pelo movimento modernista brasileiro e pelas vanguardas europeias canônicas, firmando meu interesse de pesquisa na pós-graduação em teoria literária e literatura comparada. A essa altura há que se perguntar, por que Boris Schnaiderman? Como estudante conhecia vários professores do prédio da rua Maria Antônia. Alguns, deles atuavam nas salas de aula da USP e do Mackenzie: Peterlini e Antônio de Mendonça (língua e literatura latina), Margarida Taranto e Nancy Campbel, João Fonseca (literatura inglesa, norte-americana e língua inglesa), Duílio Colombini (literaura portuguesa), Dino Preti (literatura brasileira) e outros de filologia

\footnotetext{
1 Professora Sênior Livre Docente do Departamento de Teoria Literária e Literatura Comparada - FFLCH-USP. Ex-orientanda do Prof. Boris Schnaiderman em nível de mestrado e doutorada, respectivamente com estudos sobre Serafim Ponte Grande de Oswald de Andrade e sobre a obra ficcional de Aníbal M. Machado.
} 
românica, linguística. Certos nomes eram referência em sala de aula ou conhecidos por colóquios e leituras de suplementos literários (Antonio Candido, Aderaldo Castello, Silveira Bueno, Décio de A. Prado, Alfredo Bosi, Boris Schnaiderman). Apesar de minha trajetória não incluir vínculos de formação acadêmica com a área de russo, dentre eles o que mais conhecia era o tradutor e crítico Boris Schnaiderman, por leitura intermediada por meu pai, um homem culto, interessado em literatura e versado em política. Desde longa data, na variada biblioteca de nossa casa, com mãe também leitora apurada, tivemos acesso a grandes obras de ficção e não-ficção, incluindo algumas de autores russos. Assim, cedo na adolescência, cheguei a essas traduções.

Dando por satisfeito o repertório geral da formação em letras, pelo currículo previamente enviado, acrescido dos escritores hispanoamericanos que animavam nossas leituras naqueles tempos sombrios, $\mathrm{o}$ professor Boris quis saber de meu interesse pelo modernismo brasileiro (então um estudo raro no meio acadêmico). Fora as referências de casa e de amigos de meus pais, que em mim produziram centelhas, tinha lido Macunaíma de Mário de Andrade (na época uma obra pouco lembrada) e, sobre ele e Oswald de Andrade, as informações pontuais deviam-se principalmente à leitura de Mário da Silva Brito, História do modernismo brasileiro - Antecedentes da Semana de Arte Moderna, no último ano da faculdade. Com respeito a Oswald, o encantamento também era motivado pela montagem de O Rei da Vela, feita por José Celso Martinez Correia, em1967. Na entrevista procurei articular aqui e ali o aprendizado no curso de graduação, incluindo Manuel Bandeira, Carlos Drummond de Andrade, entre outros, referindo-me a palestras de Anatol Rosenfeld (em curso de extensão, de iniciativa de nosso Grêmio estudantil), textos de Decio de Almeida Prado (o teatro estava em alta na minha geração), leituras de suplementos literários. Quando achei que a entrevista ia terminar, o professor, sempre muito atencioso, prosseguiu, explicando que, sendo sua área a da literatura russa, gostaria de saber o tinha lido nesse campo. Rápido passei pela estante de casa e me lembrei de Gógol, Almas Mortas, a isso juntando uma lembrança ainda recente, a encenação de $O$ inspetor geral (Teatro de Arena, se bem me lembro), tempos em que A. Boal e G. Guarnieri concorriam para nossos anseios de resistência. Mencionei algum poema de Maiakóvski, poeta em alta na minha geração; relembrei Gorki, A Mãe; fiz referência a Os pequenos burgueses, que antes do golpe de 1964 tinha visto no teatro, também sob a direção de José Celso. A lista reduzida se esgotava. Foi então que veio a pergunta derradeira: - 'E Dostoiévski?' Até hoje tenho dúvidas (o resto do exame pouco importa) se o ponto decisivo foi o comentário feito sobre o romance que me impactou na adolescência, ou se foi o seu título contundente, pouco citado na extensa lista de obras do escritor. Veio de chofre: - 'Humilhados e ofendidos'. 
- 'Está aceita', disse o professor, ao final da entrevista, com um largo sorriso no rosto iluminado pelo azul de seus olhos brilhantes.

O relato serve para mostrar que Boris Schnaiderman, conhecido por seu vasto conhecimento no campo da tradução e da crítica literária, somava ainda generosidade e grandeza de espírito, em tempos de muita cautela. Foi exigente nos seus questionamentos e sensível na sua avaliação. Sem ideias pré-concebidas, que era traço de seu caráter, não se deixou levar pelo sentimento de animosidade, frente a uma candidata de fora da USP, nem pelo pequeno repertório que portava no campo da literatura russa. Naquele momento considerou que, potencialmente, a candidata teria condições de encetar pesquisa sobre o modernismo brasileiro, aproveitando o campo fértil em que atuava na pós-graduação - teoria literária e literatura comparada. Ao longo de minha trajetória profissional, procurei fazer jus à confiança em mim depositada pelo querido e saudoso professor Boris. Em 1979, seu nome encabeçou as dedicatórias de meu primeiro livro - Palhaço da burguesia (Serafim Ponte Grande de Oswald de Andrade e suas relações com o universo do circo) -, resultado da dissertação de mestrado apresentada em 1978. A amizade criou raízes. Em sua casa, com Regina (que faleceu em janeiro de 1985), e depois com Jerusa, fui recebida de braços abertos, para festa, jantar, ou chá da tarde, em prolongadas conversas.

Conhecido por seu trabalho magistral, operando diretamente de sua língua-mãe para o português, segunda língua que conhecia em profundidade, Boris Schnaiderman foi considerado o pai da tradução de obras ficcionais da literatura russa no Brasil. Dispensando a intermediação das traduções francesas, que até então nos alcançavam, trouxe à luz o vigor da escrita poética de autores como Dostoiévski, Tolstói, Górki, Púchkin, Tchékhov, V. Maiakóvski, Kuprin, entre outros grandes da literatura eslava, aos quais dedicou seu trabalho. Produziu ainda traduções em parceria com poetas como Augusto e Haroldo de Campos, Nelson Ascher: Ana Akhmátova, Ossip Mandelstam, Maiakóvski... Além de ser excelente tradutor, Boris Schnaiderman destacou-se como crítico literário, o que certamente influiu no modo pelo qual lidou com o texto nas suas traduções. Nesse trabalho incessante, que o acompanhou vida afora, resumiu o ato de traduzir como "ato desmedido", título com o qual designou uma reunião de textos publicados em 2011, quando já estava com 93 anos. Isso sem contar o Boris escritor, que alargou sua dimensão humana e artística nos relatos sobre a experiência vivida na 2a. Guerra Mundial.

Nascido em Úlman, na Ucrânia, em 17 de maio de 1917, residiu em Odessa até os oito anos. Em 1925 veio para o Brasil com a família. Aqui naturalizou-se e viveu até sua morte, ocorrida em 18 de maio de 2017, um 
dia depois de completar 99 anos. Como registrou em livro, alistou-se no exército brasileiro, sendo combatente da FEB na $2^{\mathrm{a}}$. Guerra Mundial. Esse período tenebroso, de pungente choque de realidade, foi por ele exposto em Guerra em surdina (1964), que assim começa:

Pálidos, nervosos, abatidos, os homens apinhavam-se no saguão do Ministério da Guerra. Foram convocados por jornal, ao acaso segundo parecia. Outros da mesma idade continuavam nas ocupações habituais, sabendo da guerra apenas por vagas notícias, comentando os acontecimentos do mundo como se conversassem de futebol ou da carestia. E os convocados não compreendiam por que a sorte recaíra justamente sobre eles. ${ }^{2}$

Anos e anos depois, retomando o tema, reuniu outros escritos em Caderno italiano (2015). Um fragmento extraído do livro distingue seu domínio do fazer e sua sensibilidade na apreensão do mundo em redor:

Não dá para esquecer a população de Roma naqueles dias em dezembro de 1944. Mal nutridos, geralmente de ar sombrio, eu os via dirigindo-se para as ocupações cotidianas. Eles passavam por grandes e vistosos cartazes que lembravam o massacre das Fosse Adreatine, durante a ocupação alemã, quando os nazistas fuzilaram 335 civis, quase todos reféns, apanhados ao acaso, em represália à emboscada e morte dos soldados de uma patrulha alemã pelos partigiani, num bairro central de Roma.

Engenheiro agrônomo de formação, ex-pracinha, tradutor, escritor, crítico literário, Boris Schnaiderman também desempenhou papel fundante como professor-criador dos cursos de graduação de língua e literatura russa, e teve atuação de marcada importância no programa de pós-graduação em teoria literária e literatura comparada (FFLCH-USP). No campo da crítica introduziu entre nós a obra de Mikhail Bakhtin e de outros, como Iúri Lótman e Roman Jakobson. Este último, por um tempo, compôs o grupo de formalistas russos, críticos que também conhecemos por sua indicação. A propósito, no prefácio que escreveu para a publicação em português de Teoria da literatura - formalistas russos, Boris apontou questões que iam na contramão de certos juízos apregoados, argumentando:

E, quando se estuda em pormenor a contribuição dos formalistas russos, percebe-se desde o início uma tendência marcada a levar em conta a relação dialética entre sincronia e diacronia, a ver a língua como um fenômeno social e, como tal, relacionada com as demais 'séries sociais', e sobretudo uma

\footnotetext{
2 Schnaiderman, Boris. Guerra em surdina. Histórias do Brasil na 2a ${ }^{\mathrm{a}}$. Grande Guerra. São Paulo: Brasiliense, 1983, p. 7. $2^{\mathrm{a}}$. edição.
} 
acentuada importância atribuída ao estudo histórico tanto da linguagem como da sua expressão literária." 3

No campo ensaístico destacam-se dois grandes estudos: A poética de Maiakóvski (sua tese de doutorado) e Dostoiévski. Prosa e poesia (tese de livredocência). Essas publicações projetam para seu público leitor o conhecimento de fôlego enciclopédico e a solidez do aparato teóricocrítico, aliados constantes de suas rigorosas análises e interpretações.

Como orientanda do professor Boris Schnaiderman em nível de mestrado e de doutorado, convivi desde 1972 com vários colegas: Eliana Asche (que se tornou uma grande amiga), Reni Cardoso, Suzana Camargo, Rubens Pereira, Paulo Peres, Antonio Carlos Costa, Luís da Silva. Antes de nós, as orientandas Jasna Paravitch Sarhan e Helena Nazário. Por esse tempo, Aurora Bernardini já era sua assistente. Nos anos subsequentes, partilhamos nosso convívio quinzenal com Sophia Angelides e José Antônio Pasta Júnior. Em 1973, como orientador, recomendou-nos fazer o curso oferecido pelo professor Antonio Candido, "Fundamentos da análise literária", com apresentação e discussão de um diversificado corpus de teorias críticas, passando da Poética de Aristóteles à Explication du texte e a Rémy de Gourmont; depois, pela estilística de Bally, por Spitzer, Starobinski, Auerbach, entre os muitos contemplados. O curso foi mais uma instância de sedimentação crítica, ampliando nosso aprendizado, contribuindo para a definição e forja de caminhos, exigindo leituras e reflexões para afinar pesquisas e apurar crivos analíticos. Nesse início da pós-graduação, outra indicação certeira para a minha pesquisa foi o curso de Telê Ancona Lopez sobre as vanguardas europeias e o modernismo brasileiro. Outros, também fecundos, vieram nos anos subsequentes na Usp e na Unicamp (Alfredo Bosi, Onédia Barbosa, Décio de A. Prado, Roberto Schwarz). E era esse o intuito do orientador que estimulava e promovia o exercício crítico na sala de aula, nos seminários quinzenais, nos cursos, nos atendimentos individuais de orientação, na correção de nossos trabalhos, que retornavam cuidadosamente acompanhados de observações, numa caligrafia impecável.

Como professor do programa de pós-graduação, Boris Schnaiderman ofereceu no primeiro semestre de 1973 o curso "Estruturas narrativas nos contos de Dostoiévski". Partia de informações gerais sobre a difusão da literatura russa no Ocidente, no final do século 20, com as primeiras traduções motivadas por aproximações políticas. A respeito da obra de Dostoiévski, afirmava que foi somente a partir da década de 1920 que ela começou a ser percebida fora de seu território, impulsionada pelos estudos de Leonid Grossman e de Mikhail Bakhtin. Segundo o professor,

\footnotetext{
${ }^{3}$ Schnaiderman, Boris. "Prefácio" in Teoria da literatura - formalistas russos. Porto Alegra: Globo, 1971, p. XIV.
}

105|BORIS SCHNAIDERMAN: Mestre e amigo: recortes 
Dostoiévski artista (1967) de L. Grossman tinha sido a primeira obra crítica escrita sobre o autor de $O$ idiota a ser traduzida no Brasil, chegando ao conhecimento do público local com razoável atraso. Com respeito a Bakhtin, que introduziu no Brasil com pioneirismo nos anos de 1970, informava que seus escritos de 20 e 30 tinham sido retomados na União Soviética somente a partir de 1950.

Ao explorar a obra de Dostoiévski para os estudantes de pósgraduação o professor tanto examinava detidamente a fatura artística como articulava a isso o universo histórico e cultural que, então, era de conhecimento exíguo no Brasil. Naquele momento, como se sabe, a cultura russa era um interdito no país, mais um cerceamento da ditadura imposta pelo golpe de 64. Cortando relações diplomáticas com a URSS, o governo local impedia o cidadão brasileiro de pisar em quaisquer de seus territórios. Internamente, abominava e reprimia de modo ostensivo tudo que a ela estivesse relacionado: língua, arte, literatura, cultura, política...

Aqui, acompanhando anotações de aula de velhos cadernos (um deles guardado por Eliana Asche), sigo passos do professor Boris, reavivando exemplos do que apresentava e esmiuçava em suas análises, em dois dos cursos que frequentei (primeiro sobre o romance; depois sobre o conto), ambos centrados na obra de Dostoiévski, escritor que, frisava, tinha rompido padrões do romance do século 19 na Rússia. Na explicação, fazia ver que tal ruptura não era um fato isolado, envolvia problemas ligados à própria formação cultural e a inquietações no meio culto em que viveu o artista. Assim ressaltava que antes do século 19 havia na Rússia uma assimilação muito grande da cultura europeia, principalmente da França, e era predominante entre os escritores de renome. E ilustrava com a percepção crítica de Púchkin, gravada no conto "A dama de espadas".

Outra questão de fundo dizia respeito à língua russa que, segundo assinalava o professor, só a partir do século 18 foi se firmando como língua de expressão literária. Tais conhecimentos de filigrana, por ele destacados, punham em evidência problemas que poucos leitores poderiam saber sem a intermediação de um conhecedor em profundidade da língua, da literatura e da cultura de seu país de origem. Seguindo por aí o professor Boris perscrutava sua língua materna, explicando como a rica tradição oral tinha sido apresada na ficção de Dostoiévski, de modo inovador, porque até então esse recurso era desprezado na literatura culta. Com foco nesse problema asseverava que, num confronto com as línguas firmadas na literatura do Ocidente, a russa era contraditoriamente uma língua jovem, e que só na segunda metade do século 19 é que se deu a aproximação da literatura culta com a língua falada pelo povo.

Ao focalizar os contos de Dostoiévski, que datam da década de 1840, Boris Schnaiderman encorpava suas análises com problematizações da crítica. Uma delas centrava-se na oposição "clássicos versus românticos", 
fórmula por ele tachada como visão redutora. Sobre esse debate, em particular, trazia o ponto de vista de Iúri Tinianov que, divergindo daquele modo de ver, entendia ser mais importante discutir na literatura russa do século 19 a oposição "arcaizantes versus inovadores", compreendendo que tais propósitos se fundavam na raiz da língua e não em problemas de ordem externa. Com os exemplos Boris reforçava a necessidade crítica de, dialeticamente, explorar o contraditório, confrontando visões e percepções de um mesmo problema para dar força à linha argumentiva. Amparado na discussão de I. Tinianov, assinalava que alguns escritores da literatura russa valorizavam o uso da língua tradicional, enquanto outros privilegiavam a expressão mais próxima da linguagem popular. Por essa via, retomando o estudo "Os arcaizantes de Púchkin" de I. Tinianov, o professor fazia notar que já na década de 1920 o crítico argumentava com base em oposições de feição localista. Adensando o debate, trazia a disputa sobre usos da língua por um aspecto paradoxal (aqui as aspas seguem anotações de aula), explicando que entre os arcaizantes havia "os que queriam que o russo continuasse próximo ao eslavo-eclesiástico", enquanto outros arcaizantes "queriam que a literatura culta se aproximasse da literatura popular". E, mais. Acrescentava que também entre os inovadores, contraditoriamente, "havia os reacionários, ou seja, os que queriam que a língua se aproximasse da gramática francesa". Nesse particular, pondo em foco a versátil complexidade literária de Alexandr Púchkin (1799-1837), Boris colocava em projeção o talento do escritor no campo da poesia, mostrando outros vértices de sua arte transgressora. Citava como exemplo certas rupturas com as práticas de seu tempo, como a ousadia de fazer poemas sem métrica. Explicava, então, que a eficácia do procedimento se devia em boa parte a um apurado "conhecimento de ouvido", porque em Púchkin estava entranhado o ritmo da poesia russa de tradição popular. Nessa seara, por outro lado, além de escrever versos sem metrificação, fertilizados por modelos de canções antigas russas, o escritor russo começava a introduzir na sua obra uma linguagem de caráter universal, o que no início do século 19 (acentuava) era considerado absurdo. Enveredando por caminhos transgressores, ainda de acordo com Boris, o artista rompeu outros padrões ao escrever um romance em versos, Evguêni Oniêguin. A propósito dessa obra, também sinalizando operações transformadoras, ressaltava que embora o argumento do romance fosse de feição romântica, o texto exibia características de realismo psicológico, o que de modo precoce apontava para a oscilação de gênero, que mais tarde (notava o crítico) caracterizou a literatura russa.

$\mathrm{Na}$ tese de livre-docência apresentada em 1974, versando sobre o conto "O senhor Prokhartchin", Boris Schnaiderman assentou o vigor de sua crítica por várias facetas. Conjugando a tradução do conto, feita diretamente do original russo, e um capítulo dedicado a problemas teórico- 
críticos sobre a tradução, pôs em movimento de análise o tríptico autorobra-receptor, em sintonia com a formulação de Antonio Candido na introdução de Formação da literatura brasileira. Na sua longa e detida leitura de "O senhor Prokhartchin", Boris Schnaiderman articulou narrador, personagens, tom, vozes, recursos estilísticos, espaço e tempo, sustentando sua argumentação em teorias da narrativa. Nessa análise-interpretativa tracejou relações entre literatura e sociedade no fazer artístico de Dostoiévski. Na sua abordagem Boris apresentou um sumo da fortuna crítica de Dostoiévski, pouco conhecida entre nós. Trouxe a recepção da obra em seu tempo, as concepções de época, entre outras questões que aprofundou, afinou, expandiu e sistematizou na referida tese. Quando o trabalho se encontrava em fase adiantada de elaboração, Boris apresentou suas análises, pondo-as em discussão na sala de aula, no curso "Os contos de Dostoiévski". Alguns anos mais tarde, quando publicou Dostoiérski Prosa Poesia (1982), o crítico generosamente registrou entre os agradecimentos de sua "Nota prévia": "Enquanto elaborava a tese, ia discutindo o trabalho com os alunos."

Para nos orientar e preparar antecipadamente as discussões, Boris indicava textos que facultavam diferentes campos de reflexão sobre o tema. Na bibliografia figurava Mikhail Bakhtin e seu livro A poética de Dostoiévski (autor que líamos ainda pela tradução francesa, e nome grafado como Bakhtine), com uma concepção inovadora sobre a obra do artista, para a qual convergia o conceito de "romance polifônico", atrelado ao "dialogismo", à "carnavalização do mundo", à "sátira menipeia" conceitos retomados por Bakhtin em L'oeuvre de françois Rabelais et la culture populaire ao Moyen Âge et sous la Renaissance -, estudo fecundo que logo pouco depois também nos apresentou. Esse importante crítico russo, que Boris introduziu em nosso meio acadêmico, foi por ele entrevistado numa das ousadas viagens (então proibidas) que fez à URSS no início dos anos de 1970. Boris considerava Bakhtin de fundamental relevância para os estudos da obra de Dostoiévski, registrando: "obriga a rever todos os conceitos da crítica anterior." 4 Ressaltava, então, que o crítico russo apontou pela primeira vez na obra do autor de Crime e castigo procedimentos artísticos inovadores, como a mistura de prosa e verso, do elevado e do baixo, por uma via incomum, reconhecendo nisso vestígios de interlocuções com a antiga paródia - dos Diálogos de Luciano à obra de Varrão. Por esse campo exploratório, Bakhtin mobilizava na fatura artística de Dostoiévski certa tradição literária marginalizada, que remontava a Menipo de Gadara, com seus escritos caracterizados pela mistura, com zombaria das formas sérias, pelas digressões, mescla de prosa e poesia etc. - procedimento que ficou conhecido como "sátira menipeia". Cabe

4 Schnaiderman, Boris. Dostoiévski - prosa poesia. São Paulo: Perspectiva: 1982, p. 68.

108|BORIS SCHNAIDERMAN: Mestre e amigo: recortes 
assinalar, porém, que embora acatasse e sublinhasse a contribuição inovadora de Bakhtin, Boris não deixou de externar seus pontos de vista divergentes, entendendo como problemática a visão essencialmente espacial na sua leitura. Assim, argumenta:

[...] não acho correto afirmar que ele [Dostoiévski] 'quase nunca apela para a história como tal, e toda questão social e política é tratada por ele no plano da atualidade'.

E prossegue, adiante, sustentando a divergência:

Não acredito que ele [Dostoiévski] anule o tempo. O que ele anula é a sucessão linear dos acontecimentos. Como elemento importante deste processo, está a superação da estrutura do conto, tal como foi teorizada por Edgar Poe: [...]." 5

A propósito de procedimentos artísticos, lidando com noções de espaço e de tempo, personagem e narrador, Boris argumenta em relação a este último que no conto "O senhor Prokhartchin" não há onisciência narrativa. Na sala de aula chamava a nossa atenção para o fato de que no fluxo do relato as intromissões do narrador faziam retardar a sucessão dos acontecimentos. Visto assim, no exame dos movimentos desse narrador observa que ora ele é ciente do que ocorre, ora deixa as coisas vagas, em suspensão. Ainda, ao contrapor sonho e realidade, detecta um processo subversivo do autor, com indicativo de que a realidade era mais absurda do que o sonho. No fluxo da leitura, constata em sua análise que depois dos sonhos de Prokhartchin, quando não mais aparecem as intromissões da personagem, o relato ganha velocidade, e cessam as interrupções do narrador. Em questões como essas, que envolvem problemas relativos à teoria do conto, voltadas para a sucessão não-linear do tempo, Boris observa que o procedimento de Dostoiévski diverge daquele postulado por Edgar A. Poe, no ensaio “The philosophy of composition" (1846). Nesse filão comparativo, advertia que, em geral, os contos da literatura russa não se enquadravam na concepção poeana, segundo a qual era do desfecho que emanavam todas as relações causais do relato. Essa observação foi registrada no posfácio de A dama do cachorrinho e outros contos. Para confirmar, Boris recortou um trecho de uma carta de A. Tchékhov (1860-1904), em que o escritor afirma: "Contra todas as chamadas regras da arte, gosto de começar com forte e terminar com pianíssimo."6

\footnotetext{
${ }^{5}$ Idem. Op. cit., p. 86.

${ }^{6}$ Idem. "Posfácio". In: A dama do cachorrinho e outros contos de Tchekhov. São Paulo: Max Limonad, 1985. $2^{\mathrm{a}}$. edição revista e refundida. Trad. de Boris Schnaiderman.
} 
Boris também buscou demonstrar que na construção de "O senhor Prokhartchin" o artista não se valia do tempo biográfico, concentrando as ações nos pontos de crise e nas catástrofes. No uso cênico, como afirma. Na sua interpretação, Dostoiévski não procurava anular o tempo, apenas evitava a sucessão linear dos acontecimentos. Nesse particular confirmava a necessidade de seguir detidamente cada passo do relato para detectar as sutilezas do texto. Assim, em constante movimento exploratório, sua análise passava das questões gerais, externas, que envolviam a recepção do autor em seu próprio tempo, às internas, indo dos refinados manejos da língua ao ponto de vista narrativo. Com foco no tom sério-cômico, predominante no conto, Boris nos fazia notar que nos mínimos detalhes poderíamos reconhecer o trabalho exigente do artista, a começar pela escolha do título. Segundo explicava, nele já se manifesta a mistura de estilos, a combinar o elevado e o baixo, explicando que o tratamento pessoal utilizado, de feição elevada, "Senhor", entra em contradição com o termo "prokhartchin", que significa "gastar com comida". E mais, duplicando paradoxos, além de o artista transformar um termo comum em nome próprio, ele pratica outra subversão ao usar tal vocábulo para caracterizar uma personagem avarenta.

Nesses estudos da obra de Dostoiévski, com entrada para Púchkin, Tolstói, Tchékhov, o professor trazia para a sala de aula concepções críticas de Iúri Lótman, E. A. Poe, G. Lukács, M. Bakhtin, Lucien Goldman; articulava diferentes proposições dos formalistas russos, como I. Tinianov, V. Chklóvski, E. Eikenbaum, O. Brik, entre outros, que líamos por uma compilação local, baseada na coletânea francesa organizada por $\mathrm{T}$. Todorov. Textos, diga-se, que Boris cuidadosamente relia conosco, discutindo, explicando, apontando equívocos conceituais duplicados na tradução brasileira. Para os alunos que não dominavam a língua russa as informações eram valiosas. No caso de "Ritmo e sintaxe" (1920 - 1927) de Ossip Brik, por exemplo, comentava que o estudo original era mais rico, de força ensaística, esclarecendo que o texto tinha sido deformado na tradução francesa. Além disso, asseverava, toda a rica parte teórica sobre o verso russo também tinha desaparecido nas duas traduções. Afinando leituras com seus comentários e correções, a propósito do texto de R. Jakobson, "Do realismo crítico" (1921), explicava que o estudo guardava comprometimentos com certas características de seu tempo, dando como exemplo a causerie (um tipo de comentário informal sem precisão terminológica), desprezada por Jakobson. Mas, advertia Boris, ao criticar a causerie ele incorria no mesmo erro, só que no campo oposto, deixando-se levar por certo enrijecimento metodológico com o qual se pretendia padronizar a crítica. Nesse particular argumentava que era preciso recolocar o objeto literário, dar-lhe a devida importância, fazendo com que os métodos dependessem de necessidades internas da obra, e não o 
contrário. Na sequência, com eixo em "A arte como procedimento" de V. Chklóvski, objetava contra a tradução de ostraniêni como "efeito de singularidade". Era incorreta, dizia. E dava como acertado o termo "estranheza". Questões como essas, que foram explicitadas na sala de aula, reproduzidas em prefácios e nos livros que traduziu, são filtros do leitorcrítico-tradutor e representativos da séria acuidade de seu trabalho.

O extenso repertório da crítica, da literatura e da cultura russa mobilizado por Boris Schnaiderman permite, por fim, conjecturar que ao conceber a produção de seus variados estudos em território e língua alheios ao de sua origem, seja pela tradução ou por ensaios escritos em português, ele acabou urdindo, ao longo dos anos, uma vasta e fecunda história e formação crítica da moderna literatura russa, curiosamente forjada em território distante, exprimindo-se na língua que adotou por naturalização. Com isso em vista, pode-se dizer que os estudos de Boris Schnaiderman, penetrando com inteligência e discernimento crítico obras de A. Púchkin, L. Tolstói, F. Dostoévski, Gógol, A. Tchékhov, M. Górki, Isác Bábel, Aleksandr Blók, V. Khliébnikov, W. Maiakóvski, Iessiênin, Óssip Mandelstam, Ana Akhmátova, Boris Pasternak, Iúri Olecha, Guenádi Aigui, Ivan Krupin, entre outros, subvertem e rompem barreiras, trazendo por um caminho inverso uma profunda leitura de seu universo materno. Premido por circunstâncias que lhe foram impostas quando criança, Boris trouxe para bem perto o convívio com a Rússia por outro viés, abrindo espaço para fazer de sua crítica um importante capítulo nos estudos da literatura russa, tanto aqui como no seu território de origem. Essa mobilização visceral talvez tenha sido um modo de viver a contrapelo, e com intensidade, a terra materna. Nessa rua de mão dupla, pode-se dizer que, amealhando o melhor da literatura ficcional de seu país de origem, num território alheio a ela, Boris Schnaiderman pode repartir com brasileiros, como ele, o "biscoito fino" da cultura russa. Internacionalista, Boris Schnaiderman fecundou na sua jornada a socialização de seu saber.

Maria Augusta Fonseca possui graduação (bacharelado e licenciatura) em Letras (Português e Inglês) pela Universidade Mackenzie (1966); mestrado em Letras (Teoria Literária e Literatura Comparada) pela Universidade de São Paulo (1977); doutorado em Letras (Teoria Literária e Literatura Comparada) pela Universidade de São Paulo (1985). É professora livre-docente em Teoria Literária pela Universidade de São Paulo (2006), e professor adjunto em Literatura Brasileira pela Universidade Federal de Santa Catarina, onde lecionou de 1992 a 1996. Ao longo dos anos, desde seu ingresso no programa de pós-graduação, obteve diferentes bolsas de pesquisa dos seguintes órgãos de fomento: Fapesp, Vitae, CNPq. Desde 1997, fez parte do corpo docente do Departamento de Teoria Literária e Literatura Comparada, da Faculdade de Filosofia, Letras e Ciências Humanas da Universidade de São Paulo. 